\title{
Qualitative Risk Analysis of IBR Introduction to Ethiopia via the Legal Importation of Bulls from Netherlands
}

\author{
Hagos Asgedom, Kuastros Mekonnen Belaynehe* \\ National Animal Health Diagnostic and Investigation Center, Epidemiology Unit, Sebeta, Ethiopia
}

Email address:

kusta@yahoo.com (K. M. Belaynehe)

${ }^{*}$ Corresponding author

\section{To cite this article:}

Hagos Asgedom, Kuastros Mekonnen Belaynehe. Qualitative Risk Analysis of IBR Introduction to Ethiopia via the Legal Importation of Bulls from Netherlands. Animal and Veterinary Sciences. Vol. 9, No. 3, 2021, pp. 80-87. doi: 10.11648/j.avs.20210903.16

Received: April 23, 2021; Accepted: June 15, 2021; Published: June 29, 2021

\begin{abstract}
Infectious bovine rhinotracheitis/infectious pustular vulvovaginitis (IBR/IPV) is a highly contagious viral disease of domestic and wild cattle causing high economic loss in cattle industry. The disease is caused by bovine herpes virus 1 (BoHV-1). BHV-1 is distributed worldwide including the exporting country Netherlands except it has been eradicated from Austria, Denmark, Finland, Sweden, Switzerland and Norway. To know the status of the disease in Ethiopia, 1430 sera samples were collected starting from January 3- 26, 2016 from four regions. However, samples are not yet processed. As part of the genetic improvement of the local breeds, the ministry of livestock and fishery of Ethiopia has already decided to import 120 bulls in March 2016 for semen production. Before the importation this bulls, an import risk assessment of IBR/IPB was conducted with the objective of assessing the risk of introduction of BHV1 to Ethiopia through the importation of infected bulls from Netherlands. Hence, hazard identification conclusion revealed the introduction of BHV1 or its abortifacient strains are regarded as potential hazards. Following the entry of infected bulls, the likelihood establishment and transmission of IBR to formerly imported breed and indigenous cattle was indicated to be high. The overall likelihood occurrence of IBR following the importation of infected bulls was assessed to be high. Potentially exotic strains of bovine herpes viruses would cause significant health impact in susceptible cattle including illness, abortion, stillbirth, neonatal death and calf mortality thereby leading to high economic losses in cattle industry. However there would little effect on people and environment. The overall level of consequence of IBR was assessed to be minor. In general, the overall risk of IBR occurrence following the importation of infected bull was estimated from moderate to high. However, this risk can be mitigated if bulls intended for importation are sourced from IBR/IPB free country and healthy check-up and detection capacity of infected animals at entry point of Ethiopia is intensified, the awareness of animal health workers and farm owners about IBR is raised with enhanced surveillance system and diagnostic capacity of the BHV1 in the importing country.
\end{abstract}

Keywords: Bovine Herpes Virus, Bulls, Semen, Importation, Risk Analysis

\section{Introduction}

Infectious bovine rhinotracheitis/infectious pustular vulvovaginitis (IBR/IPV) is highly contagious viral disease of domestic and wild cattle causing high economic losses throughout the world [1]. It is caused by bovine herpesvirus 1 $(\mathrm{BoHV}-1))$. The virus is now recognized to cause a wide range of other clinical conditions in cattle, including infertility, abortion, encephalitis, conjunctivitis, mastitis, dermatitis and enteritis [2]. It is listed as reportable diseases by the World Organization for Animal Health (OIE), although OIE-listed diseases compulsory national control program does not present in many countries for BoHV-1 [3,4].

BoHV-1 is a member of the genus Varicellovirus in the subfamily Alphaherpesvirinae, which is the member of the Herpesviridae family, order Herpesvirales. BoHV-1 is primarily involved in respiratory infection (infectious bovine rhinotracheitis, IBR), genital disease (vulvovaginitis/pustular balanoposthitis, IPV/IBP) and abortion [5]. Sporadically, BoHV-1 is connected with encephalitis [1, 6]. BoHV-1 infections passes via three different stages: a primary infection that extends up to 2 weeks, succeed by a lifelong latent infection, occasionally followed by renewed virus shedding for several days caused due to reactivation of latent 
virus that [7].

The health condition of the host is the primary factor for the reactivation and re-excretion of BoHV-1. The sensory ganglia of the nerves that innervate the sites of the primary infection are among the tissues where BoHV-1 virus remains latent are. For instance, among the tissues are the trigeminal ganglia after a respiratory infection and the lumbo-sacral ganglia after a genital infection [8]. The nuclei of neuronal cells are the site where viral DNA remains in [7]. In reality, due to animal-to-animal transmission, animals that have a genital BoHV-1 infection also manifest a BoHV-1 respiratory infection [9]. For this reason for the purpose of detecting genomic DNA of latent BoHV-1 trigeminal ganglia is a preferred site.

Where regulation does exist, the principal approach to control and eradicate IBR in high prevalence areas has been achieved through the use of vaccination with marker/DIVA (Differentiating Infected from Vaccinated) vaccines [10-12].

BHV-1 is distributed worldwide and has been diagnosed in all countries tested. The virus has been eradicated from Norway, Switzerland, Sweden, Finland, Denmark and Austria [3] while Canada and the United States, Belgium, Italy and Germany have control programs in place for it. In The Netherlands the disease is endemic. The country has been implementing a voluntary disease control program which is run by the GD (Dutch Animal Health Service) starting from 1999. However, different literatures showed the disease is still prevalent. In dairy and mixed farm herd prevalence was recorded to $84 \%$ [13]. Data collected during 2004 showed $69 \%$ and $76 \%$ herd prevalence in dairy and Beef farms respectively. A report of surveillance on animal health situation in Netherland conducted during 2015 showed only $45 \%$ of dairy farms are IBR-free (www.gdanimalhealth.com). The Netherlands have announced plans to launch a compulsory IBR and BVD control program in 2017 and are conducting research to determine which methods are the most effective and costefficient

(http://www.bvdzero.com/bvd_news/articles_papers/Netherla nds_eradication_BVD.html).

In Ethiopia, Studies regarding to IBR/IBP were not carried out so far. Hence the status of the disease is unknown in Ethiopia. The objective of this study was to qualitatively assess the risk of introduction of IBR to Ethiopia via the legal importation of bulls from Netherland and to determine the prevalence of the diseases in Ethiopia.

\section{Materials and Methods}

Risk analysis was conducted using structured interview, literature and manual reviews. National animal health diagnostic and investigation center (NAHDIC) and the national data bases were also assessed if previous work was done about IBR.

\subsection{Scope and Commodity Definition}

This risk assessment concerns with the importation of cattle (bull or heifer). Cattle to be imported must be prepared to standards equivalent to those recommended for cattle in the OIE Terrestrial Animal Health Code1 (here after referred to as the Code). The assessment considers any formal importation of cattle (bull or heifer), from the above mentioned country. It refers only to IBR which is OIE listed disease [14].

A bull is an intact (not castrated) adult male of the species Bos taurus (cattle). More muscular and aggressive than the female of the species and plays a significant role in reproduction.

\subsection{Risk Questions}

What is the risk of introduction of IBR per year into Ethiopia via importation of infected cattle/bulls from Netherlands?

What is the likelihood establishment of IBR and risk of transmission to other susceptible hosts through semen artificial insemination (AI) or live bull in Ethiopia?

What is the risk of IBR infection of all intensive farms and possibility of transmission to local breeds of cattle?

\subsection{Assessment of Risk with Animal Importation}

The ranking of animal importation in relation to their risk of IBR introduction was carried out according to a set of criteria. For each of those criteria, a risk score was assigned, so that, the higher the numerical score, the higher the risk. The entry assessment describes the probability of the entry of each of the IBR to Ethiopia under each specified set of conditions with respect to amounts and timing, and how these might change as a result of various actions, events or measures [15].

\subsection{Hazard Identification}

This involves identifying the pathogenic agents which could potentially produce adverse consequences associated with the importation of a bull or semen.

\subsection{Determination of Ethiopia's Status}

The status of the disease can be measured using pathological, clinical and laboratory measures. A general literature review was made to determine if any report describing the disease frequency in Ethiopia.

\section{Results and Discussions}

\subsection{Etiological Agent}

Biologic Properties of the Species: Bovine herpesvirus 1 (BHV-1) is a member of the family Herpesviridae, subfamily Alphaherpesvirinae Genus: Varicellovirus [16]. The virus is associated with infectious bovine rhinotracheitis (IBR) and infectious pustular balanoposthitis/ infectious pustular vulvovaginitis (IPV/IPB) [17]. Restriction endonuclease analysis of DNA is a molecular technique used to identify the virus subtypes, such as, BHV1.1 and BHV1.2 [18, 19]. BHV- 
1 subtype 1.1 is associated with respiratory signs and Rhinitis, while subtype 1.2 is associated with balanoposthitis and pustular vulvovaginitis. There is a future classification on subtype 1.2 strains, namely, BHV1.2a and BHV1.2b. Some subtype1.1 and 1.2a strains are abortifacient, as shown by close connection with clinical cases of abortion and by experimental infection of pregnant heifers [20]. Although not related with abortion, subtype $1.2 \mathrm{~b}$ strains are commonly linked with respiratory and genital infections [21-23] (Table $1)$.

Table 1. Strains of Bovine herpes virus 1 for hazard identification.

\begin{tabular}{lllll}
\hline \multirow{2}{*}{ Type } & \multicolumn{4}{l}{ Syndrome } \\
\cline { 2 - 5 } & IBR & IPV/IPB & Abortion & Encephalitis \\
\hline BHV1.1 & + & - & + & - \\
BHV1.2a & + & + & + & - \\
BHHV1.2b & + & + & - & - \\
\hline
\end{tabular}

\subsection{The Status of IBR in Ethiopia}

The status of BHV1 is not known in Ethiopia due to lack of investigations. Abortion signs have been observed in different regions of the county but not confirmed so far whether due to BHV1 or other infectious diseases. Currently about 1430 sera samples are collected from intensive and extensive farms of four regions for serology test. However test results are not included in this review due to time shortage.

Even though the status of IBR/IBV is still not know in Ethiopia, however, a single report [24] estimated both the animal and herd level seroprevalence of BHV1 in selected geographic regions of Ethiopia. By any means the introduction of BHV1 or its abortifacient strains are known as a potential hazard. So it is necessary to regard all BHV1.1 and BHV1.2a strains as hazards.

\subsection{Risk Assessment}

\subsubsection{Entry Assessment}

There are many reports confirming that seminal shedding of BHV1 detected in bulls [22, 25, 26]. Hence, there is a possibility that sub clinically infected stags may excrete the virus in their semen and the likelihood of introduction of BHV1 through infected bulls is estimated to be high (Figure 1).

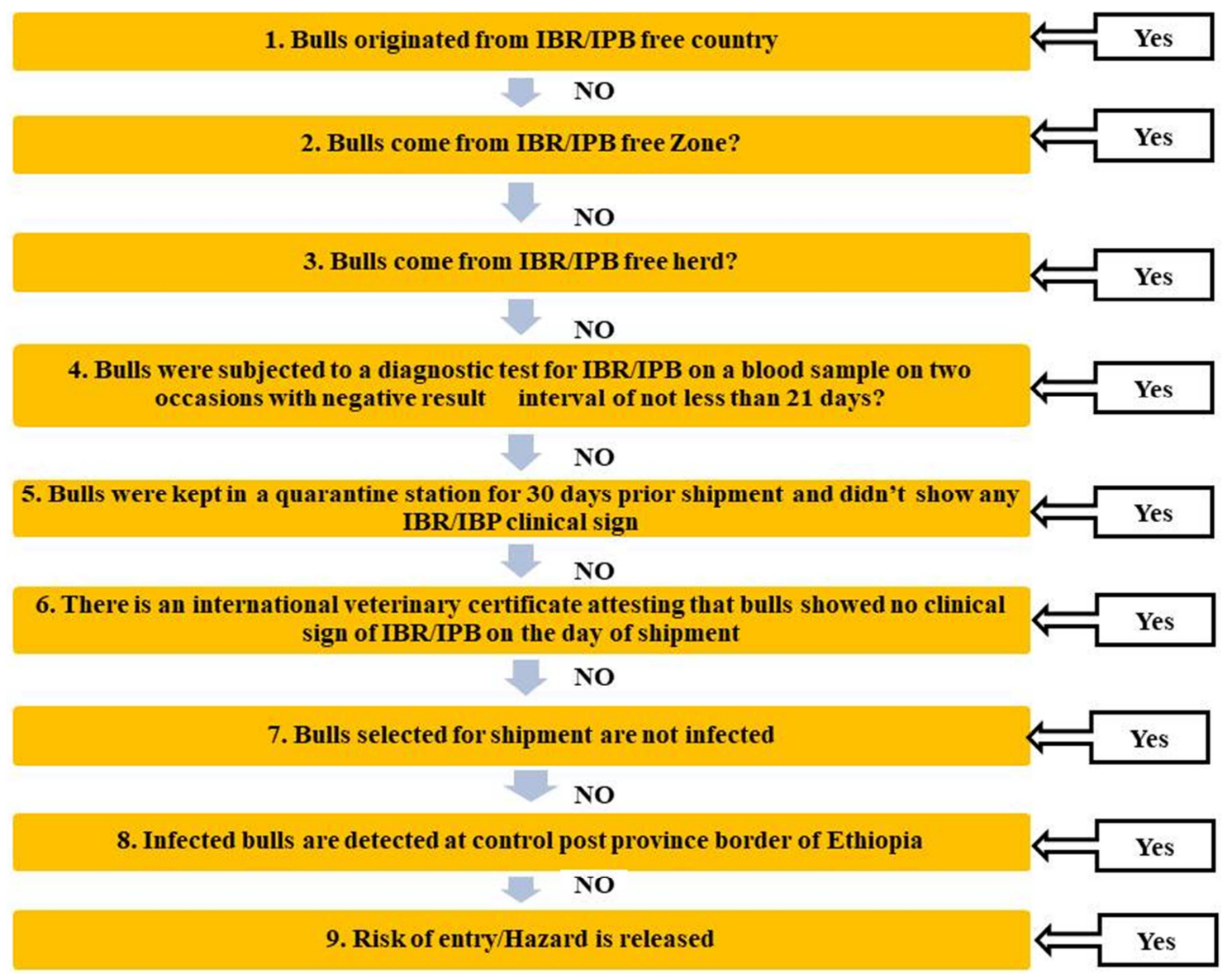

Figure 1. Risk pathway Development for BHV1 release assessment (BHV1 entry assessment stage).

\subsubsection{Exposure Assessment}

Since semen which is collected and processed at NAHDIC will be inseminated into recipients of different regions, the likelihood of exposure of different farms is certain (Figure 2).
Susceptible recipients could likely get IBR/ IPV virus infection when contaminated with infected semen [27, 28]. It has been estimated that as few as 32 virus particles in semen may be needed to infect a susceptible cow [22] and the probability that insemination will turn out to infection of the 
susceptible recipients is high. Infected cattle may also shed the virus in their aerosols and nasal secretions for up to 14 days following infection [18], subsequently intra and inter farms transmission and dissemination of IBR/IPV will be high. Hence, the likelihood of exposure of naïve indigenous cattle to potentially exotic strains of bovine herpes viruses linked with semen is evaluated to be high (Table 2).

Table 2. Analysis of risk pathway with tabulating the risk areas and identifying risk factors for each area.

\begin{tabular}{|c|c|c|c|}
\hline Risk areas & Risk factors that increase likelihood & Relevant information & $\begin{array}{l}\text { Estimating level } \\
\text { of likelihood }\end{array}$ \\
\hline $\begin{array}{l}\text { IBR/IPB existence } \\
\text { at the source country }\end{array}$ & $\begin{array}{l}\text { Inadequate disease control in source } \\
\text { country }\end{array}$ & Bulls are sourced from a source country which is not free of IBR & High (4) \\
\hline $\begin{array}{l}\text { Selection of infected } \\
\text { bulls for shipment }\end{array}$ & $\begin{array}{l}\text { Bulls originate from a zone / farm not } \\
\text { free of IBR }\end{array}$ & $\begin{array}{l}\text {-No IBR free area/zone is established in the exporting country } \\
\text {-IBR herd prevalence at source country is } 53.5 \% \text { (surveillance } \\
\text { results of 2015) }\end{array}$ & High (4) \\
\hline $\begin{array}{l}\text { No detection of } \\
\text { infected bulls by } \\
\text { health inspection } \\
\text { prior shipment }\end{array}$ & $\begin{array}{l}\text { Low health check and detection } \\
\text { capacity of infection }\end{array}$ & $\begin{array}{l}\text {-IBR infection can be subclinical/ IBR usually exists as latent } \\
\text { infection } \\
\text {-Even antibody cannot be detected by Serological tests }\end{array}$ & High (4) \\
\hline $\begin{array}{l}\text { No detection of } \\
\text { infected bulls at } \\
\text { entry point }\end{array}$ & $\begin{array}{l}\text { Low inspection operation and } \\
\text { facilities at entry point }\end{array}$ & $\begin{array}{l}\text {-Entry (Bole airport) inspection point facilities don't set up in such } \\
\text { a way that it allows proper inspection and isolation of infected } \\
\text { animals. } \\
\text {-IBR can exist at latent infection }\end{array}$ & High (4) \\
\hline $\begin{array}{l}\text { No IBR detection } \\
\text { and report from } \\
\text { bulls at NAIC center }\end{array}$ & $\begin{array}{l}\text {-Poor IBR surveillance system and } \\
\text { Inadequate diagnostic capacity. } \\
\text {-Poor awareness about IBR } \\
\text {-Nature of the disease } \\
\text { (subclinical/latent) }\end{array}$ & $\begin{array}{l}\text { - The surveillance system in Ethiopia is not well strong in early } \\
\text { detecting exotic and endemic cases. } \\
\text {-The awareness and knowledge of animal health workers and farm } \\
\text { owners about IBR is considerably low } \\
\text { - Animals can be sero-negative latent carriers (SNLC) }\end{array}$ & Medium (3) \\
\hline $\begin{array}{l}\text { Serving of farms } \\
\text { with infected } \\
\text { bull/semen }\end{array}$ & $\begin{array}{l}\text { Bulls/Semen is not tested for BHV1 } \\
\text { which can be transmitted via AI } \\
\text { service. }\end{array}$ & $\begin{array}{l}\text { Bulls that have been infected via venereal transmission can excrete } \\
\text { the virus in their semen }\end{array}$ & High (4) \\
\hline $\begin{array}{l}\text { Dams and progeny } \\
\text { Infection }\end{array}$ & $\begin{array}{l}\text { Semen/bull is not tested for BHV1 } \\
\text { that can be transmitted via AI /live } \\
\text { bull service. }\end{array}$ & $\begin{array}{l}\text { IBR transmission is common from contaminated semen/bull } \\
\text { through use of AI or live breeding }\end{array}$ & High (4) \\
\hline $\begin{array}{l}\text { Rapid within and } b / n \\
\text { farm transmission of } \\
\text { IBR }\end{array}$ & $\begin{array}{l}\text {-Due to close contact } \\
\text {-Untreatable } \\
\text {-No herd immunity } \\
\text {-Nature of the disease } \\
\text {-Low biosecurity }\end{array}$ & $\begin{array}{l}\text {-IBR is highly contagious diseases. } \\
\text { Transmission is also direct (nose-to-nose) contact } \\
\text { - No effective treatment but antibiotics for secondary infection \& } \\
\text { complication. } \\
\text { - IBR vaccine is not available in Ethiopia }\end{array}$ & High (4) \\
\hline $\begin{array}{l}\text { IBR spread and } \\
\text { dissemination to } \\
\text { local breeds }\end{array}$ & $\begin{array}{l}\text {-Low biosecurity } \\
\text {-Untreatable disease } \\
\text {-No herd immunity } \\
\text {-Aerosol transmission }\end{array}$ & $\begin{array}{l}\text {-Local breeds can be also served with AI /bulls for genetic } \\
\text { improvement } \\
\text {-Disease transmission is possible between the exotic and local } \\
\text { breeds due to the contagious nature of the disease. } \\
\text {-There is low/no local herd immunity } \\
\text { - The latent nature of the infection and the related spontaneous } \\
\text { virus reactivation }\end{array}$ & High (4) \\
\hline $\begin{array}{l}\text { Occurrence of } \\
\text { infection leading to } \\
\text { abortion, neonatal } \\
\text { death, calf mortality } \\
\text { and adult illness in } \\
\text { cattle }\end{array}$ & $\begin{array}{l}\text {-Herd are susceptible } \\
\text {-Herd are not immunized/ vaccinated }\end{array}$ & $\begin{array}{l}\text {-IBR can cause abortion if susceptible cows or heifers are infected } \\
\text { during pregnancy. } \\
\text {-Early embryonic death can also occur. } \\
\text { - Neonatal death can be resulted when cows get Infected during the } \\
\text { last trimester of their gestation, } \\
\text {-Death of weak calves occurs during the first } 2 \text { weeks of life. } \\
\text {-Latent infection can occur } \\
\text { - A high mortality rate can be induced with some highly virulent } \\
\text { BHV-1 strains. }\end{array}$ & High (4) \\
\hline Overall score $^{\#}$ & & High $(3.9)^{* *}$ & 39 \\
\hline
\end{tabular}

"In a scale of 1-4, level of likelihood can be scored as follows: VL-1; L-2; M-3; H-4.

\#Overall likelihood: Average total score $=36 / 9=3.8$ (high)

${ }^{* *}$ The likelihood occurrence of IBR following the importation of infected bulls is therefore high if the risk factors remain constant

\subsubsection{Consequence Assessment}

There are many evidences/literatures which suggest that bovine herpes virus 1 would cause significant illness, abortion, stillbirth, neonatal death and calf mortality especially the introduction of abortifacient strains would have damaging economic outcome for cattle industry.
Therefore the consequences are estimated to be nonnegligible. Wild and feral ruminants such as sheep and goats could become infected but it is unlikely for the virus to result in a considerable disease in these animals. However there would little consequences for people, since bovine herpes viruses are not considered as a zoonotic disease. In addition, the consequence of IBR on environment is also assessed to 
be negligible (Table 3).

\begin{tabular}{l} 
1. Infected bulls are imported by NAIC \\
2. Infected semen is produced and collected for by NAIC from infected bulls \\
3. Infected semen/bulls are distributed to regional AI centers \\
4. Infected semen/bulls are distributed to all dairy farms in different regions \\
5. Dairy cattle are served with AI having infected Semen \\
6. Infection is transmitted to progeny \\
9. Farm infection occur leading to abortion \\
9. Disease transmission to local breeds occur \\
10. Still birth, neonatal and calf mortality, Abortion, infertility, production loss in adult cattle \\
\hline Yes
\end{tabular}

\section{Yes}

High economic loss in cattle industry

Figure 2. Development of Risk pathway for IBR/IPB transmission (exposure assessment stage).

Table 3. Identifying categories and level of consequences associated with IBR exposure and establishment.

\begin{tabular}{|c|c|c|}
\hline Consequence Category & $\begin{array}{l}\text { Consequence level } \\
\text { (score*) }\end{array}$ & Justification of the score \\
\hline Effect on cattle health (Death, injury or illness & Moderate (3) & $\begin{array}{l}\text { Can cause abortion in susceptible pregnant cows, neonatal death, death of } \\
\text { weak calves }\end{array}$ \\
\hline Effect on human health (public health impact) & Insignificant (1) & IBR is not zoonotic disease \\
\hline Socioeconomic impact (loss of market/business & Major (4) & $\begin{array}{l}\text { Abortion, neonatal death, infertility, reduced milk production can lead to } \\
\text { significant socio-economic loss }\end{array}$ \\
\hline Image/trade impact & Moderate (3) & -Bad image of the NAIC but less trade effect \\
\hline Environmental impact & Insignificant (1) & little environmental impact \\
\hline Overall score $^{\#}$ & Minor $(12 / 5=2.4)$ & \\
\hline
\end{tabular}

${ }^{*}$ Consequence levels in a scale of 1-5, the consequence scores are: insignificant-1; Minor-2; Moderate-3; major-4; catastrophe-5.

"The overall level consequence of IBR is Minor $(12 /=2.4)$.

\subsection{Risk Estimation}

Based on the assumption that IBR is established and transmission may occur from infected recipients to other susceptible herd, the exposure, entry, and outcome assessments are all non-negligible. Hence, the risk assessment for IBR is nonnegligible. Basically, BHV1 strains are categorized as risks in the commodity and cause economic losses in cattle industry, risk management measures need to be justified (Table 4).

$$
\begin{gathered}
\text { Risk }=\text { Likelihood } \times \text { Consequence } \\
=\text { high (3.8) } \times \text { Minor }(2.4) \\
\text { Risk }=\text { high }
\end{gathered}
$$

The overall occurrence of risk of IBR/IBP is from Moderate to high. 
Table 4. Determining the level of risk associated with IBR occurrence following the importation of infected bulls using risk rating matrix.

\begin{tabular}{llllll}
\hline \multirow{2}{*}{ Likelihood } & Consequences & & & & \\
\cline { 2 - 6 } & $\mathbf{1}(\mathbf{i n s})$ & $\mathbf{2}(\mathbf{m i n})$ & $\mathbf{3}$ (mod) & $\mathbf{4}$ (major) & $\mathbf{5}(\mathbf{c a t})$ \\
\hline A-high & High & high & Extreme & Extreme & Extreme \\
B-Moderate & Moderate & High & High & Extreme & Extreme \\
C-low & Low & Moderate & High & Extreme & Extreme \\
D-very low & Low & Low & Moderate & High & Extreme \\
E-Rare & Low & Low & Moderate & High & High \\
\hline
\end{tabular}

\subsection{Risk Mitigation Measures}

As a measure to prevent disease introduction, bulls intended for importation should be sourced from IBR/IPB free country (Veterinary authorities of importing country should demand the presentation of an international veterinary certificate attesting that the animals came from IBR/IPV free country/zone/herd). Equally important is bulls selected for exportation should be kept in isolation for duration of 30 days, and throughout this period they have been subjected to a laboratory examination for IBR/IPB on a blood sample on two instances with negative results, at an interval of not less than 21 days.

Veterinary authorities of importing country should demand the presentation of an international veterinary certificate attesting that the bulls do not manifest clinical sign of IBR/IPV on the day of shipment. Moreover, the presentation of an international veterinary certification is a requirement to testify that bulls were detain in a quarantine station for the 30 days ahead of departure and were subjected to a laboratory examination for IBR/IPV on a blood sample on two occasions with negative results, at an interval of not less than 21 days. The exhibition of an international veterinary certificate also demanded from the Importing country position to certify that bulls were vaccinated with an inactivated virus vaccine not less than one month and not more than six months before departure. This point is very important for importation of cattle intended from herds not qualified as free from IBR/IPV. Since boarder entry points are important route, intensifying health checkup and detection capacity of infected cattle at boarder entry point of Ethiopia and quarantine for about 30 day (IBR IP is 21 days) before introducing with other local herds should be practiced.

There should be awareness creation platforms and programs for animal health workers and farm owners about IBR, enhance the surveillance system and diagnostic capacity of IBR in importing country. Laboratory testing for IBR/IPB on a blood sample for individual bulls at an interval of not greater than 3 month should be done. Collection of the semen should be done from a donor bulls that were kept in an IBR/IPV free herd. If the bull is serologically positive or if the serological status of the bull is unknown, an aliquot of each semen sample collected should be subjected to molecular test using PCR or a virus isolation test should be performed. With negative results, the semen would be collected, processed and stored in accordance with the procedures and guidelines applicable to AI centers for semen collection facilities and semen laboratories.

\section{Conclusions}

Bovine Herpes virus 1 continues to spread as a significant pathogen globally and has a considerable impact on cattle health and cattle industry. Due to the latent nature of the infection and the associated spontaneous virus reactivation, the infected animal remains infective throughout its life time. Diagnostic tests, such as, VNT and glycoproteins B (gB) specific ELISAs was concluded as the most sensitive tests for the detection of antibodies in serum. The herd prevalence of the exporting country (Netherlands) was reviewed to be high. However, the status of the disease is unknown in Ethiopia so far. Hazard identification conclusion revealed the introduction of BHV1 especially its abortifacient strains (subtype 1.1 and 1.2a strains) are regarded as potential hazards. The overall likelihood occurrence of IBR following the importation of infected bulls was assessed to be high but the overall level of consequence of IBR was determined to be minor. In general, the overall risk of IBR occurrence following the importation of infected bull was estimated from moderate to high. Applying restrict sanitary regulations incoherence with the OIE standard is necessary in mitigating the risk of introduction of IBR/IPB to Ethiopia.

Therefore; based on the above conclusion the following recommendations were made

1. The origin of the bulls should be from a BHV-1 free herd in a BHV-1 free zone and country where the exporting country's applied surveillance program provides a sufficient chance of $99.8 \%$ that herds are not infected.

2. The semen donor bull found at Ethiopian National Artificial Insemination Center (NAIC) must be free of IBR/IPB infection which is implemented by conducting a regular diagnostic tests before the distribution of semen to regions/farms,

3. Positive animals need to be removed from the herd which is followed by strict biosecurity measures that prevent further introduction of the virus.

4. The Detection capacity and surveillance system of Ethiopia need to be intensified in establishing IBR/IPB free center/area providing sufficient probability (99.8\%) that bulls/ herds are not infected in NAIC or regional AI center before the distribution of semen to regions/farms

5. Further studies on IBR disease need to be conducted the status to understand the epidemiology of the diseases in Ethiopia. 


\section{Abbreviation}

Artificial insemination-AI

Bovine herpes virus-BHV

Bovine viral Diarrhea-BVD

Differentiating Infected from Vaccinated-DIVA

Enzyme-linked immunosorbent assay- ELISA

Infectious Bovine Rhinotracheitis/infectious pustular vulvovaginitis-IBR/IPV

National Artificial Insemination Center-NAIC

Virus neutralization test-VNT

World organization for animal health-OIE

\section{Conflict of Interest}

The Authors have no conflicts of interest to declare.

\section{Acknowledgements}

The authors would like to acknowledge the National animal health diagnostic and investigation Center (NAHDIC) for provision of data.

\section{References}

[1] Silva, M. S., Brum, M. C. S., Loreto, E. L. S., Weiblen, R., Flores, E. F., 2007. Molecular and antigenic characterization of Brazilian bovine herpesvirustype 1 isolates recovered from the brain of cattle with neurological disease. Virus Res. 129, 191-199.

[2] Straub, O. C., 2001. Advances in BHV1 (IBR) research. Deutsche Tierärztliche Wochenschrift 108, 419-42.

[3] Ackermann, M., Engels, M., 2006. Pro and contra IBReradication. Veterinary Microbiology 113, 293-302.

[4] Sayers, R. G., Byrne, N., O'Doherty, E. and Arkins, S., 2015. Prevalence of exposure to bovine viral diarrhoea virus (BVDV) and bovine herpesvirus-1 (BoHV-1) in Irish dairy herds. Research in Veterinary Science, 100, pp. 21-30.

[5] Kahrs, R. F. (Ed.), 2001. Infectious bovine rhinotracheitis and infectious pustular vulvovaginitis. Viral Diseases of Cattle. Iowa State University Press, Ames, IA, pp. 159-170.

[6] Roels, S., Charlier, G., Letellier, C., Meyer, G., Schynts, F., Kerkhofs, P., Thiry, E., Vanopdenbosch, L., 2000. Natural case of bovine herpesvirus 1 meningo-encephalitis in adult cow. Vet. Rec. 146, 586-588.

[7] Muylkens, B., Meurens, F., Schynts, F., Farnir, F., Pourchet, A., Bardiau, M., Gogev, S., Thiry, J., Cuisenaire, A., Vanderplasschen, A., et al., 2007. Intraspecific bovine herpesvirus 1 recombinants carrying glycoprotein E deletion as a vaccine markerare virulent in cattle. Journal of General Virology 87, 2149-2154.

[8] Van Engelenburg, F. A., Van Schie, F. W., Rijsewijk, F. A., Van Oirschot, J. T., 1995. Excretion of bovine herpesvirus 1 in semen is detected much longer by PCR than by virus isolation. J. Clin. Microbiol. 33, 308-312.

[9] Mollema, L., Koene, P., de Jong, M. C., 2006. Quantification of the contact structure in a feral cattle population and its hypothetical effect on the transmission of bovine herpesvirus 1. Prev. Vet. Med. 77, 161-179.

[10] Mars, M. H., De Jong, M. C. M., Van Maanen, C., Hage, J. J. and Van Oirschot, J. T., 2000. Airborne transmission of bovine herpesvirus 1 infections in calves under field conditions. Vet. Microbiol, 76 (1): 1-13.

[11] Nandi, S, Kumar M, Manohar M, Chauhan R. 2009. Bovine herpes virus infections in cattle. Animal Health Research Reviews; 10: 85-98.

[12] Nardelli, S., Farina, G., Lucchini, R., Valorz, C., Moresco, A., Dal Zotto, R., Costanzi, C., 2008. Dynamics of infection and immunity in a dairy cattle population undergoing an eradication programme for infectious bovine rhinotracheitis (IBR). Preventive Veterinary Medicine 85, 68-80.

[13] Van Wuijckhuise, L., Bosch, J., Franken, P., Frankena, K., Elbers, A. R., 1998. Epidemiological characteristics of bovine herpes virus 1 infections determined by bulk milk testing of all Dutch dairy herds. Veterinary Record 142, 181-184.

[14] OIE, 2010. Infectious bovine rhinotracheitis/ infectious pustular vulvovaginitis. Version adopted by the World Assembly of Delegates of the OIE; Chapter 2.4.13.

[15] OIE, 2019, Section 2 Risk analysis, Chapter 2.1. Import Risk analysis. Article 2.1.1. 2019 Terrestrial Animal Health Code 28/06/2019.

[16] Davison, A. J., Eberle, R., Ehlers, B., Hayward, G. S., McGeoch, D. J., Minson, A. C., Pellett, P. E., Roizman, B., Studdert, M. J., Thiry, E., 2009. The order Herpesvirales. Arch. Virol. 154, 171-177.

[17] Brock, J., Lange, M., Guelbenzu-Gonzalo, M., Meunier, N., Vaz, A. M., Tratalos, J. A., Dittrich, P., Gunn, M., More, S. J., Graham, D. and Thulke, H. H., 2020. Epidemiology of agedependent prevalence of Bovine Herpes Virus Type 1 (BoHV1) in dairy herds with and without vaccination. Veterinary research, 51 (1), pp. 1-13.

[18] Malla, J. A., Chakravarti, S., Gupta, V., Chander, V., Sharma, G. K., Qureshi, S., Mishra, A., Gupta, V. K. and Nandi, S., 2018. Novel polymerase spiral reaction (PSR) for rapid visual detection of bovine herpesvirus 1 genomic DNA from aborted bovine fetus and semen. Gene, 644, 107-112.

[19] Dagalp, S. B., Farzani, T. A., Dogan, F., Alkan, F. and Ozkul, A., 2020. Molecular and antigenic characterization of bovine herpesvirus type 1 (BoHV-1) strains from cattle with diverse clinical cases in Turkey. Tropical animal health and production, 52 (2), pp. 555-564.

[20] Petrini, S., Iscaro, C. and Righi, C., 2019. Antibody responses to bovine alphaherpesvirus 1 (BoHV-1) in passively immunized calves. Viruses, 11 (1), 23.

[21] Fulton, R. W., d'Offay, J. M., Dubovi, E. J. and Eberle, R., 2016. Bovine herpesvirus-1: Genetic diversity of field strains from cattle with respiratory disease, genital, fetal disease and systemic neonatal disease and their relationship to vaccine strains. Virus research, 223, 115-121.

[22] van Oirschot, J. T., Kaashoek, M. J., Rijsewijk, F. A., Stegeman, J. A., 1996. The use of markervaccines in eradication of herpesviruses. Journal of Biotechnology 44, 7581. 
[23] Kramps J. A., Banks M., Beer M., Kerkhofs P., Perrin M., Wellenberg G. J. \& van Oirschot J. T., 2004. Evaluation of tests for antibodies against bovine herpesvirus 1 performed in national reference laboratories in Europe. Vet Microbiol., 102, 169-181.

[24] Sibhat, B., Ayelet, G., Skjerve, E., Gebremedhin, E. Z. and Asmare, K., 2018. Bovine herpesvirus-1 in three major milk sheds of Ethiopia: Serostatus and association with reproductive disorders in dairy cattle. Preventive veterinary medicine, 150, 126-132.

[25] Oliveira, M. T., Campos, F. S., Dias, M. M., Velho, F. A., Freneau, G. E., Brito, W. M. E. D., Rijsewijk, F. A. M., Franco, A. C. and Roehe, P. M., 2011. Detection of bovine herpesvirus 1 and 5 in semen from Brazilian bulls. Theriogenology, 75 (6), pp. 1139-1145.
[26] Nuotio, L., Neuvonen, E. and Hyytiäinen, M., 2007. Epidemiology and eradication of infectious bovine rhinotracheitis/infectious pustular vulvovaginitis (IBR/IPV) virus in Finland. Acta Veterinaria Scandinavica, 49 (1), 1-6.

[27] Bielanski, A., Algire, J., Lalonde, A. and Garceac, A., 2014. Risk of transmission of bovine herpesvirus-1 (BHV-1) by infected semen to embryo recipients and offspring. Reproduction in Domestic Animals, 49 (2), 197-201.

[28] Reichel, M. P., Wahl, L. C. and Hill, F. I., 2018. Review of diagnostic procedures and approaches to infectious causes of reproductive failures of cattle in Australia and New Zealand. Frontiers in veterinary science, 5, 222. 